\title{
MRSA on surface: is it possible to control?
}

\author{
CN Shimura*, D De Andrade, E Watanabe, AM Ferreira, NEPECISS \\ From International Conference on Prevention \& Infection Control (ICPIC 2011) \\ Geneva, Switzerland. 29 June - 2 July 2011
}

\section{Introduction / objectives}

The prevalence of Methicillin-resistant Staphylococcus aureus (MRSA) in generally is low, however may become easily resistant to multiples antibiotics. The aim of this study was to compare two disinfectants: Peractic Acid $0.1 \%$ and Etilic Alcohol $70 \%$ on surfaces contaminated with MRSA.

\section{Methods}

This is a case control study, developed on a flowchart. Six sterile glasses surfaces $(40 \times 30 \mathrm{~cm})$ were contaminated with a suspension with $10^{4} \mathrm{cfu} / \mathrm{ml}$ MRSA by spreading with a sterile spatula and left dry for $10 \mathrm{~min}$. The efficacy of desinfections products were measure by imprinting rodac plates with Trypticase Soy Agar holding for $1 \mathrm{~min}$ against the surface, before and after the desinfection procedure. The glass surface was divided in three parts and each part was cleaned three times. A sterile microfibre cloth $(40 \times 38 \mathrm{~cm})$ made by $10 \%$ polyester, $20 \%$ polypropylene and $70 \%$ viscose were folded three times, total sixteen sides, but using nine sides only; they were moistened with $50 \mathrm{ml}$ of $0.1 \%$ Peractic Acid or Etilic Alcohol $70 \%$ to clean three surfaces each. Furthermore, sterile gloves were used and had their imprints (both hands) made on rodac plates, holding for 15s. Plates were incubated at $37^{\circ} \mathrm{C}$ for $48 \mathrm{~h}$.

\section{Results}

The median of surface contamination before and after disinfection with Peractic Acid was $3.55 \mathrm{cfu} / \mathrm{ml}$ and 0 $\mathrm{cfu} / \mathrm{ml}$, for Etilic Alcohol, $4.26 \mathrm{cfu} / \mathrm{ml}$ and $0 \mathrm{cfu} / \mathrm{ml}$ respectively. Imprints of gloves after both disinfections had no growth $(0 \mathrm{cfu} / \mathrm{ml})$. The test showed a bacterial load reduction although a non-significant $(\mathrm{p}>0.05)$ result comparing solutions.

Escola de Enfermagem de Ribeirão Preto - USP, Ribeirão Preto, Brazil

\section{Conclusion}

Proceeding disinfection with Peractic Acid $0.1 \%$ or Etilic Alcohol 70\% associating adequate technique had successful bacterial load reduction which contributes for environment control. Peracetic Acid has a good cost benefit however the microfibre cloth was degradating after 5 times.

\section{Disclosure of interest}

None declared.

Published: 29 June 2011

doi:10.1186/1753-6561-5-S6-P307

Cite this article as: Shimura et al:: MRSA on surface: is it possible to control? BMC Proceedings 2011 5(Suppl 6):P307.
Submit your next manuscript to BioMed Central and take full advantage of:

- Convenient online submission

- Thorough peer review

- No space constraints or color figure charges

- Immediate publication on acceptance

- Inclusion in PubMed, CAS, Scopus and Google Scholar

- Research which is freely available for redistribution

\section{() Biomed Central}

